\title{
Peripheral Metabolism of Insulin, Proinsulin, and C-Peptide in the Pregnant Rat
}

\author{
Adrian I. Katz, Marshall D. Lindheimer, Mary E. Mako, and \\ Arthur H. Rubenstein \\ From the Departments of Medicine and Obstetrics and Gynecology, The \\ Pritzker School of Medicine, The University of Chicago, Chicago, Illinois 606.37
}

A в S T RACT To clarify alterations in carbohydrate metabolism which occur in pregnancy, metabolic clearance rates of insulin, proinsulin, and $\mathrm{C}$-peptide were measured by the constant infusion technique in term-pregnant rats and in virgin littermates. In addition, placental permeability to these peptides was evaluated by simultaneous determination of their concentration in fetal blood, amniotic fluid, and maternal arterial blood, and the renal extraction and excretion of insulin and $\mathrm{C}$-peptide were determined during simultaneous studies of renal hemodynamics.

The metabolic clearance rate (MCR) of insulin was higher $(P<0.005)$ in pregnant animals $(61.5 \pm 1.7 \mathrm{ml} /$ min per $\mathrm{kg}$ nonconceptus body weight) than in virgin littermates $(51.5 \pm 2.2 \mathrm{ml} / \mathrm{min}$ per $\mathrm{kg})$. Insulin disappearance from the circulation after both single injection and discontinuance of a constant infusion was also faster in gravid animals. In contrast, the $\mathrm{MCR}$ of proinsulin and $\mathrm{C}$-peptide, and the disappearance of C-peptide from the circulation were similar in pregnant and control rats. The placenta was virtually impermeable to each of the three polypeptides since their mean levels in both fetal blood and amniotic fluid did not exceed $2.5 \mathrm{ng} / \mathrm{ml}$ and were only minimally influenced by pharmacological concentrations as high as $60 \mathrm{ng} / \mathrm{ml}$ in the maternal circulation. The renal clearance of insulin (renal arteriovenous insulin difference $\times$ renal plasma flow) was lower, and its contribution to insulin MCR was less in pregnant animals than in controls $(19.4 \pm 1.5 \%$ vs. $28.7 \pm 3.7 \%$, $P<0.05)$, whereas the renal clearance and renal clearance/MCR of $\mathrm{C}$-peptide were similar in pregnant rats and virgin littermates.

A preliminary report of this work was presented at the 32nd Annual Meeting of the Midwest Section, American Federation of Clinical Research and was published in abstract form in 1974; Clin. Res. 22: 472 and 617.

Received for publication 5 June 1975 and in revised form 4 . August 1975.
These results indicate that the peripheral metabolism of insulin is accelerated in pregnancy, while that of proinsulin and C-peptide is unaffected. Since transplacental passage of insulin is negligible and its renal clearance is not increased, the enhanced MCR of insulin in pregnancy is due to increased metabolism at an extrarenal site probably within the placenta itself.

\section{INTRODUCTION}

Pregnancy is accompanied by numerous changes in carbohydrate metabolism, including elevated plasma insulin concentrations in both the fed and fasted state (1). Recently, additional beta cell secretory products, namely proinsulin and $\mathrm{C}$-peptide, have been identified in the blood and their relationship to insulin has been determined in various conditions such as islet cell tumors (2), renal failure (3), diabetes (4), and pregnancy.' While the metabolism of insulin has been studied in pregnant humans and animals (5), little is known about the metabolic fate of the other two peptides during gestation. Such information is necessary in order to interpret the significance of changes in the relative concentrations of circulating insulin, proinsulin, and C-peptide.

We have previously measured the peripheral metabolic clearance rates $(\mathrm{MCR})^{2}$ of insulin, proinsulin, and $\mathrm{C}$-peptide in rats (6) and demonstrated the major contribution of the liver (7) and kidneys (6) to their re-

\footnotetext{
${ }^{1}$ Phelps, R. L., R. Bergenstal, N. Freinkel, A. H. Rubenstein, B. E. Metzger, and M. E. Mako. 1975. Carbohydrate metabolism in pregnancy. XIII. Relationships between plasma, insulin, and proinsulin during the late pregnancy in normal and diabetic subjects. Manuscript in preparation.

${ }^{2}$ Abbreciations used in this paper: $\mathrm{C}_{\mathrm{In}}$, clearance of inulin; $\mathrm{C}_{\mathrm{PAH}}$ and $\mathrm{E}_{\mathrm{PAH}}$, clearance and extraction of $p$-aminohippurate; GFR, glomerular filtration rate; MCR, metabolic clearance rate; RPF, renal plasma flow.
} 
moval. In the present study we have evaluated the peripheral metabolism of these three peptides in term-pregnant and virgin littermate rats with special emphasis on the permeability of the placenta to insulin, proinsulin, and $\mathrm{C}$-peptide and to quantitative changes in their renal clearance. $^{s}$

\section{METHODS}

Female littermate rats of the Sprague-Dawley strain were paired and caged together after weaning. One animal from each pair was bred when 8 wk old (Charles River Breeding Laboratories, Wilmington, Mass.) and studied during its 20 gestational day simultaneously with its virgin littermate, which served as control. All animals had free access to tap water and were fed standard rat chow until the afternoon preceding the experiment, when food was withdrawn. All experiments were started between 8 and 9 a.m., after approximately $16 \mathrm{~h}$ of fasting.

$M C R$. Animals were prepared as described below under Renal Function. After a priming injection $(200-500 \mathrm{ng})$, either bovine insulin $(30 \mathrm{ng} / \mathrm{min})$, proinsulin $(7.5 \mathrm{ng} / \mathrm{min})$, or C-peptide $(20 \mathrm{ng} / \mathrm{min})$ were administered by constant infusion at a rate of $40 \mu \mathrm{l} / \mathrm{min}$. After $1 \mathrm{~h}$ of equilibration, four to five arterial blood samples were obtained at $30 \mathrm{~min}$ intervals. MCR's were calculated by dividing the infusion rate by the steady-state plasma concentrations (8): MCR = (infusion rate)/(plasma concentration), and are reported both in absolute terms and corrected for body weight. In pregnant animals, nonconceptus weight was measured by subtracting the weight of the uterus and contents from total body weight.

Polypeptide disappearance curves. Arterial plasma concentrations of insulin and C-peptide were measured after 90 min of continuous infusion and at short time intervals after discontinuing their administration. In the case of insulin, arterial levels were also measured after a single intravenous injection. In the continuous infusion studies, each polypeptide was infused at a rate of $100 \mathrm{ng} / \mathrm{min}$, and in several experiments insulin was also infused at the rate of $200 \mathrm{ng} /$ min. Three arterial blood samples were obtained $15 \mathrm{~min}$ apart before the infusion was stopped and eight additional samples at 2-5 min intervals thereafter. In the single injection study, $8 \mu \mathrm{g} / \mathrm{kg}$ body weight insulin was given rapidly, intravenously after which six arterial blood samples were obtained at 5-10 min intervals. Plasma levels are expressed as percent of the last value before the infusion was stopped, or of the value measured at $5 \mathrm{~min}$ in the single injection experiments.

Placental permeability. Each polypeptide was infused at different rates (insulin, 50 and $500 \mathrm{ng} / \mathrm{min}$; proinsulin, 7.5, 30 , and $200 \mathrm{ng} / \mathrm{min}$; C-peptide, 20, 200, and $600 \mathrm{ng} / \mathrm{min}$ ) into pregnant animals to obtain a wide range of steadystate plasma concentrations. To prevent severe hypoglycemia in the high-dose insulin experiments, dextrose in a $20 \%$ solution was administered at the rate of $8 \mathrm{mg} / \mathrm{min}$ together with the insulin. After a $1 \mathrm{~h}$ equilibration period, three arterial blood samples were drawn at $30 \mathrm{~min}$ intervals. Immediately after the last sample, the uterus was removed and amniotic fluid and fetal heart blood from several fetuses

${ }^{3}$ Throughout this study renal clearance denotes milliliters of plasma cleared of each polypeptide by the kidney in $1 \mathrm{~min}$ and should not be confused with the urinary clearance which represents only the negligible fraction of the former that can be accounted for by urinary excretion. were collected in heparinized capillary tubes; admixture with maternal blood was carefully avoided. The crossreactivity of endogenous insulin, proinsulin, and C-peptide in the bovine assays was measured in separate experiments in maternal arterial blood, amniotic fluid, and fetal heart blood of noninfused animals.

Renal function. Animals were anesthetized with Inactin (Promonta, Hamburg, West Germany) $120 \mathrm{mg} / \mathrm{kg}$ intraperitoneally, a tracheostomy was performed, and the bladder, a jugular vein, and one carotid artery were cannulated with polyethylene PE50 catheters. After exposure of the left renal vein, the adrenal and ovarian veins were ligated and the rats were placed on a heated animal board. Rectal temperature, monitored by a thermistor probe (Yellow Springs Instrument Co., Yellow Springs, Ohio) was maintained between $37^{\circ}$ and $38^{\circ} \mathrm{C}$. During surgery, isotonic saline equal to $0.5-1 \%$ of the body weight was infused intravenously to replace estimated fluid losses.

After priming doses of $20 \mathrm{mg}$ inulin and $3 \mathrm{mg} p$-aminohippurate $(\mathrm{PAH})$ were administered, a sustaining solution calculated to maintain plasma levels at approximately 50 and $3 \mathrm{mg} / 100 \mathrm{ml}$, respectively, was delivered with constant infusion pumps (Harvard Model 975; Harvard Apparatus Co., Inc., Millis, Mass.) at the rate of $40 \mu \mathrm{l} / \mathrm{min}$. Either bovine insulin or C-peptide were infused in separate experiments, together with the infusion of inulin and $\mathrm{PAH}$. After an equilibration period of $60 \mathrm{~min}$, urine was collected under mineral oil and volumes were measured with glass micropipettes. In each experiment collections from three to four consecutive periods of $30 \mathrm{~min}$ each were obtained, and arterial blood was drawn in heparinized capillary tubes before and after each collection period. After completion of urine collections, two arterial samples were drawn simultaneously with two renal venous blood samples for measurement of $\mathrm{PAH}$ and polypeptide extraction. Renal venous blood was withdrawn slowly with gauge 27 needles into heparinized tuberculin syringes.

Urinary clearances of insulin, C-peptide, inulin, and $\mathrm{PAH}$ were calculated from their respective urine: plasma concentration ratios and the urine flow by standard formulas. $\mathrm{PAH}$ extraction $\left(\mathrm{E}_{\mathrm{PAH}}\right)$ was calculated from the arterial $\left(A_{P A H}\right)$ and renal venous $\left(R_{P_{P A}}\right)$ concentration of $\mathrm{PAH}$ :

$$
E_{\mathrm{PAH}}=\frac{\mathrm{A}_{\mathrm{PAH}}-\mathrm{R} V_{\mathrm{PAH}}}{\mathrm{A}_{\mathrm{PAH}}} \times 100,
$$

and renal plasma flow (RPF) from the ratio of $\mathrm{PAH}$ clearance $\left(\mathrm{C}_{\mathrm{PAH}}\right)$ to $\mathrm{PAH}$ extraction:

$$
\mathrm{RPF}=\mathrm{C}_{\mathrm{PAH}} / \mathrm{E}_{\mathrm{PAH}} \times 100 .
$$

Extraction of insulin and of C-peptide was derived from concentrations in arterial and renal venous samples analogous to the extraction of PAH. Renal clearance of these polypeptides was estimated from the product of their respective extraction rates and the renal plasma flow, and expressed in milliliters per minute.

Materials. The characteristics of the bovine insulin, proinsulin, and C-peptide which were used in these experiments have been described previously (6). The insulin was purified from first crystals (kindly supplied by the Novo Company, Copenhagen, Denmark). Immunoassay of fractions after gel filtration showed that the insulin was essentially free of early eluting components. The infusate was prepared in isotonic saline from a stock solution of the polypeptide $(400$ $\mu \mathrm{g} / \mathrm{ml}$ ) dissolved in a Tris- $\mathrm{HCl}$ buffer $(\mathrm{pH} 7.4)$ containing $1 \%$ bovine serum albumin to prevent loss by adsorption onto glassware or polyethylene tubing. The polypeptide concen- 
trations in the infusates were verified by measuring an aliquot together with the blood and urine samples from the same experiment.

Gel filtration. Selected maternal plasma samples (0.1$0.5 \mathrm{ml}$ ) were gel filtered $(9,10)$ on $1 \times 50 \mathrm{~cm}$ columns of Biogel P-30 (Bio-Rad Laboratories, Richmond, Calif.), equilibrated in $3 \mathrm{M}$ acetic acid (C-peptide experiments) and borate albumin buffer, $\mathrm{pH} 8.2$ (insulin and proinsulin experiments). Portions of each of the column fractions were assayed in the insulin, proinsulin, and C-peptide assays as previously described (6).

Chemical and immunological methods. Glomerular filtration rate (GFR) and effective renal plasma flow (ERPF) were calculated from the clearance of inulin and PAH. Plasma and urine concentrations of inulin and $\mathrm{PAH}$ were determined in duplicate samples by semimicro modifications of the anthrone (11) and diazotization (12) methods, respectively. The polypeptides were measured by a modification of the double antibody immunoassay of Morgan and Lazarow (13). Bovine [ $\left.{ }^{125} \mathrm{I}\right]$ proinsulin and a purified bovine proinsulin antiserum which did not cross-react with rat insulin at concentrations up to $20 \mathrm{ng} / \mathrm{ml}$ were used to assay bovine proinsulin. Bovine $\mathrm{C}$-peptide was measured with a bovine proinsulin antiserum and synthetic [ $\left.{ }^{125} \mathrm{I}\right]$ tyrosyllated bovine C-peptide (kindly supplied by Dr. N. Yaniahara, College of Pharmacy, Shizuoka-Shi, Japan). Because bovine insulin proinsulin, and C-peptide were infused in separate experiments, the individual assay characteristics described above ensured the specific measurement of each infused peptide.

Results are presented as mean \pm 1 SEM. Statistical significance was assessed by Student's $t$ test and $P$ values less than 0.05 were considered significant.

\section{RESULTS}

Preliminary experiments. Because rat and bovine insulin cross-react in the insulin assay, we used a similar approach to that described previously (6) to obviate the interfering effect of endogenous insulin. In preliminary experiments the blood sugar of pregnant rats lay

\section{TABLE I}

$M C R$ of Insulin, Proinsulin, and C-Peptide in Pregnant Rats and Virgin Littermates

\begin{tabular}{|c|c|c|c|c|}
\hline & & $\begin{array}{l}\text { Steady state plasma } \\
\text { concentration }\end{array}$ & Metabolic c & learance rate \\
\hline & $n$ & $n g / m l$ & $m l / m i n$ & $\begin{array}{c}\mathrm{ml} / \mathrm{min} \text { per } \mathrm{kg} \\
\text { body weight* }\end{array}$ \\
\hline \multicolumn{5}{|l|}{ Insulin } \\
\hline Pregnant & 11 & $2.31 \pm 0.10 \ddagger$ & $13.2 \pm 0.6$ & $61.5 \pm 1.7$ \\
\hline Control & 11 & $2.89 \pm 0.14$ & $10.6 \pm 0.5$ & $51.5 \pm 2.2$ \\
\hline$P$ & & $<0.005$ & $<0.01$ & $<0.005$ \\
\hline \multicolumn{5}{|l|}{ Proinsulin } \\
\hline Pregnant & 9 & $2.76 \pm 0.26$ & $3.0 \pm 0.4$ & $15.2 \pm 1.9$ \\
\hline $\begin{array}{l}\text { Control } \\
P\end{array}$ & 9 & $\begin{array}{c}2.52 \pm 0.20 \\
\text { NS }\end{array}$ & $\begin{array}{l}3.1 \pm 0.2 \\
\mathrm{NS}\end{array}$ & $\begin{array}{l}15.8 \pm 0.8 \\
\mathrm{NS}\end{array}$ \\
\hline \multicolumn{5}{|l|}{ C-Peptide } \\
\hline Pregnant & 12 & $4.11 \pm 0.20$ & $5.0 \pm 0.2$ & $24.2 \pm 1.0$ \\
\hline $\begin{array}{l}\text { Control } \\
P\end{array}$ & 12 & $\begin{array}{c}4.69 \pm 0.24 \\
\text { NS }\end{array}$ & $\begin{array}{l}4.4 \pm 0.5 \\
\mathrm{NS}\end{array}$ & $\begin{array}{l}23.8 \pm 1.0 \\
\text { NS }\end{array}$ \\
\hline
\end{tabular}

* In pregnant animals, hody weight minus uterus and products of conception.

$\ddagger \pm$ SEM.

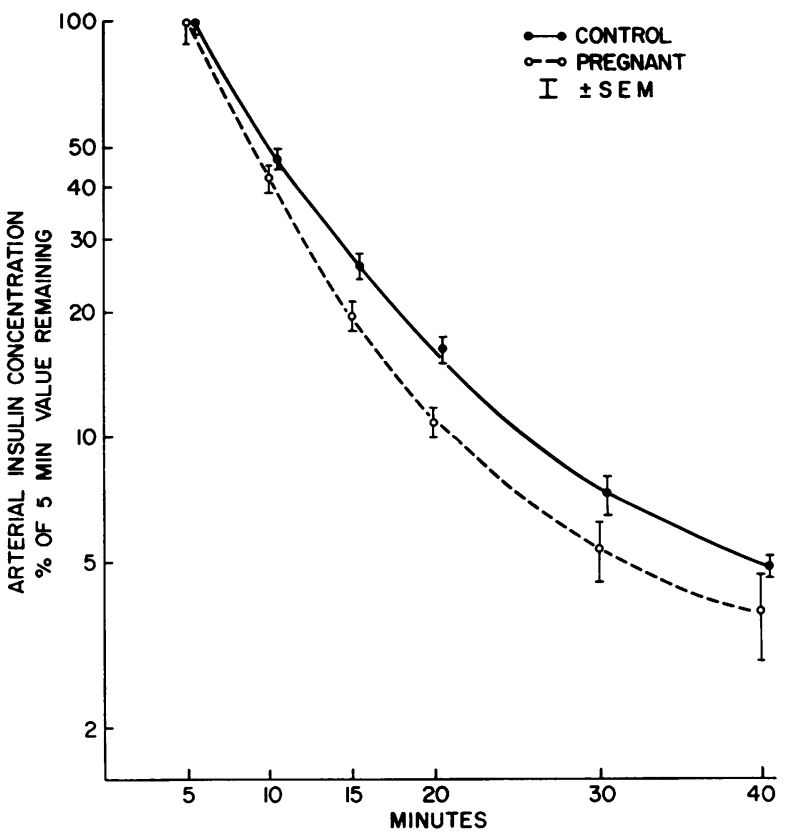

Figure 1 Plasma levels of insulin in pregnant and virgin littermate rats after injection of the hormone $(8 \mu \mathrm{g} / \mathrm{kg}$ body weight) at time zero. The results are expressed as a percentage of the $5 \mathrm{~min}$ concentrations $13.4 \pm 1.6 \mathrm{ng} / \mathrm{ml}$ in pregnant animals and $12.8 \pm 0.8 \mathrm{ng} / \mathrm{ml}$ in controls.

between 58 and $74 \mathrm{mg} / 100 \mathrm{ml}$ after $60 \mathrm{~min}$ infusion with the lowest concentration of insulin used $(30 \mathrm{ng} / \mathrm{min}$ ). As fasting pregnant rats with blood sugars above this range $(72-90 \mathrm{mg} / 100 \mathrm{ml})$ have plasma insulin levels below $0.5 \mathrm{ng} / \mathrm{ml}$, we concluded that the contribution of endogenous insulin to the total plasma insulin concentrations would be small.

In selected experiments, rats were exsanguinated at the time the final blood sample was obtained. A number of procedures were then carried out to verify the direct immunoassay results. These included measurement of different volumes of plasma (25-250 $\mu 1)$, recovery of standards added to plasma, and identification of the peptides in their expected position on gel filtration. The results were similar in all respects to those obtained in nonpregnant rats (6). Specifically, conversion of proinsulin to insulin or C-peptide did not occur. The sensitivity of the insulin and $\mathrm{C}$-peptide assays would have permitted detection of conversion of 0.1-0.2 ng of proinsulin.

$M C R$. The mean metabolic clearance rate of insulin, both in absolute terms and when related to nonconceptus body weight, was significantly higher in pregnant animals than in their virgin littermates (Table I). In contrast, the MCRs of proinsulin and C-peptide were similar in pregnant and control animals. In both groups, insulin MCR was considerably faster than that of either 


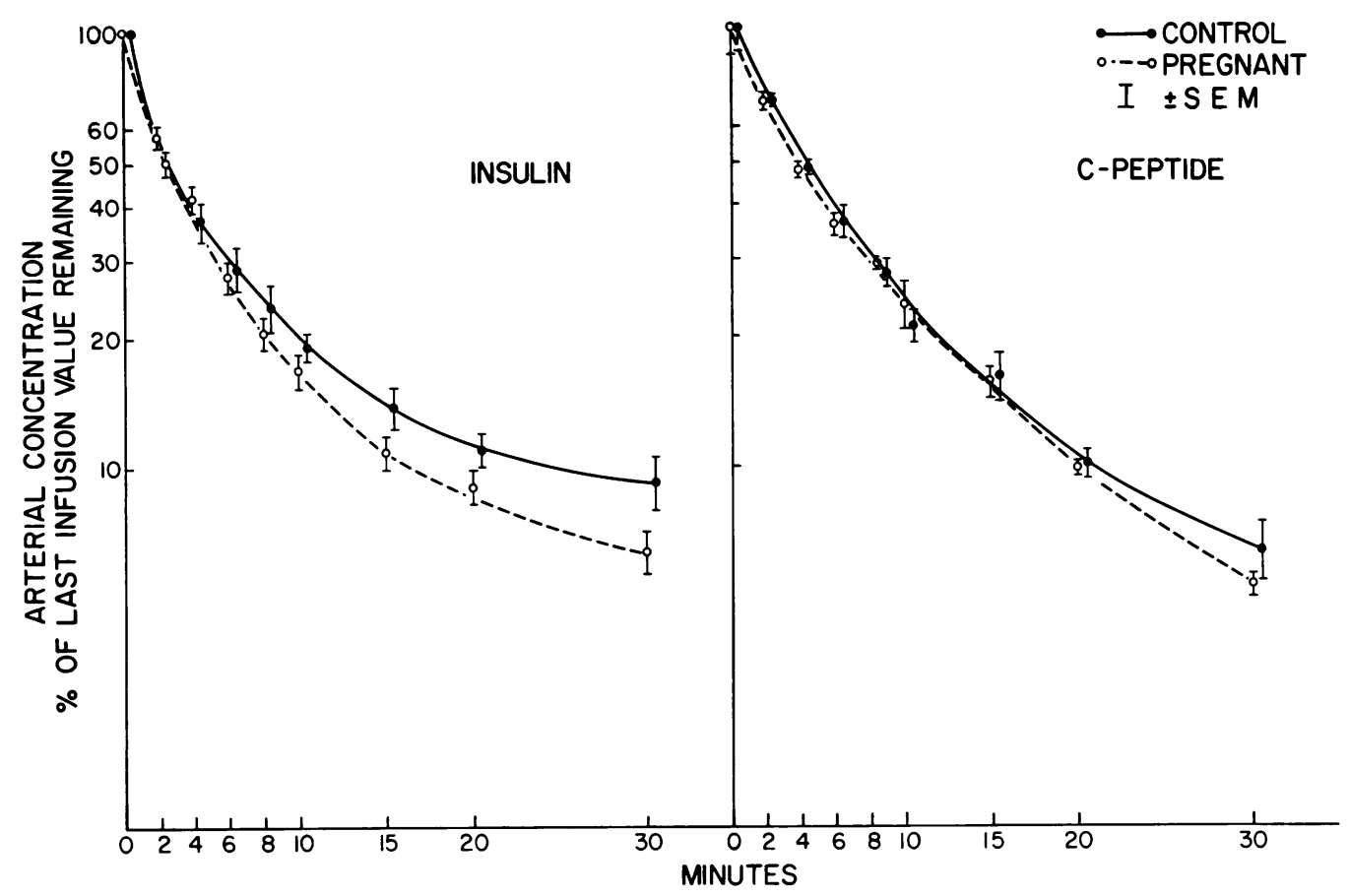

FIGURE 2 Plasma levels of insulin (left) and C-peptide (right) in pregnant and virgin littermate rats after discontinuance of a $90 \mathrm{~min}$ constant infusion. The results are expressed as a percentage of the arterial blood concentration just before the infusion was stopped. (Insulin $15.7 \pm 2.4 \mathrm{ng} / \mathrm{ml}$ in pregnant animals and $16.0 \pm 2.4$ in controls; C-peptide $17.2 \pm 2.2 \mathrm{ng} / \mathrm{min}$ in pregnant rats and $20.7 \pm 2.4 \mathrm{ng} / \mathrm{ml}$ in controls).

proinsulin or C-peptide, in agreement with previously reported results in male rats (6).

Polypeptide disappearance curves. (a) Single injection: Plasma levels in 11 pregnant and 11 control animals were related to the first measured value $5 \mathrm{~min}$ after injection. The disappearance of insulin from the circulation followed a multi-exponential curve in both pregnant and control animals (Fig. 1). Insulin disappearance was faster in pregnant animals, the difference reaching statistical significance at 15 and $20 \mathrm{~min}$ after injection.

(b) Constant infusion: To avoid possible errors due to the distribution of insulin in various body compartments after single injection, we measured the disappearance of insulin after plasma concentrations had reached a steady-state after $90 \mathrm{~min}$ of constant infusion. Results of experiments in which the insulin infusion rate was $100 \mathrm{ng} / \mathrm{min}$ ( 12 pairs of rats) and $200 \mathrm{ng} / \mathrm{min}$ (6 pairs) were similar and are therefore plotted together (Fig. 2). As in the single injection study, the decay curves followed a multi-exponential pattern. The mean values in the pregnant rats were lower than in the controls from 6 to $50 \mathrm{~min}$, but only the $30 \mathrm{~min}$ time point was significantly different in the two groups. The decay curves of C-peptide (Fig. 2) were almost identical in pregnant rats $(n=6)$ and in controls $(n=6)$. Examination of the early part of the decay curves reveals that the disappearance rate of insulin was much faster than that of C-peptide, in agreement with the measured MCRs of these two polypeptides (Table I).

Placental permeability. After the infusions, concentrations of insulin, proinsulin, and C-peptide in amniotic fluid and fetal blood were low and were little affected by marked increments in their levels in the maternal circulation (Fig. 3). Thus, the mean concentration of each of the three polypeptides did not rise above 2.5 $\mathrm{ng} / \mathrm{ml}$ in fetal fluids even when mean maternal blood levels exceeded $60 \mathrm{ng} / \mathrm{ml}$. Although it is possible that a small amount of insulin, proinsulin, and C-peptide may cross the placenta, none of the polypeptides appeared in the fetal circulation in appreciable quantities, regardless of the maternal concentrations achieved. Samples taken from noninfused animals are shown as circled symbols in Fig. 3. It should be noted that these values are significantly higher than the levels in control sera from numerous other experiments which did not exceed $0.2 \mathrm{ng} / \mathrm{ml}$. We do not have an explanation for these findings.

Renal handling of insulin and C-peptide (Table II). The urinary clearance of insulin was higher in preg- 

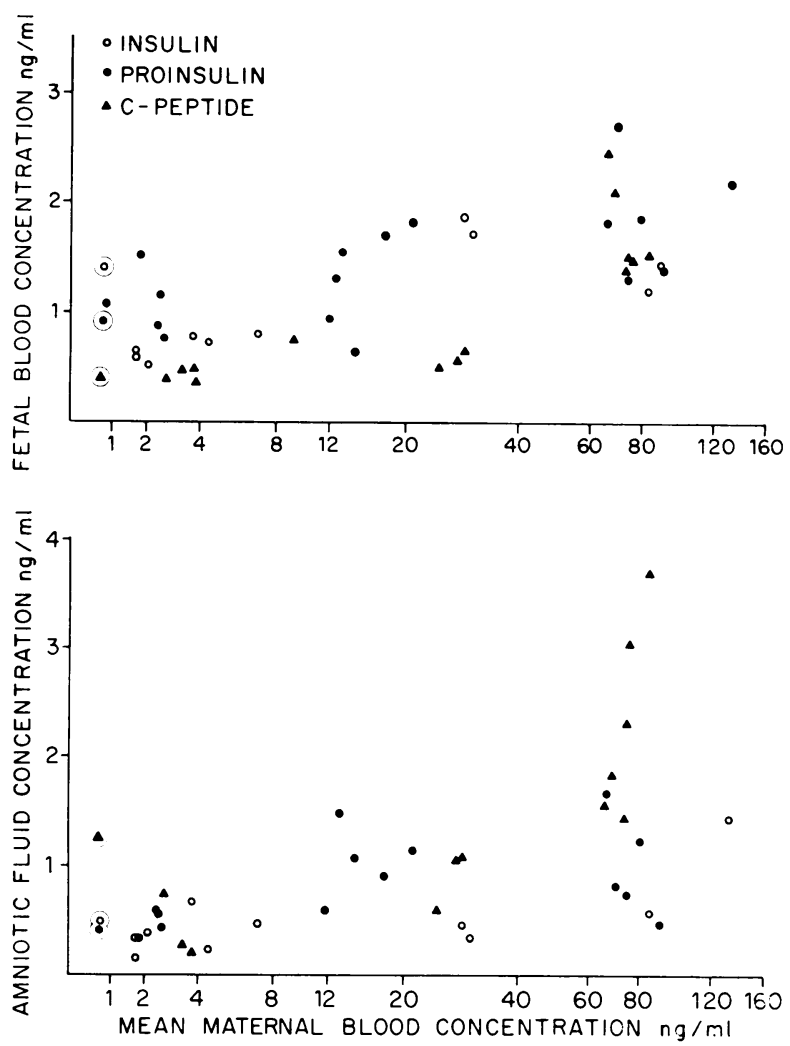

Figure 3 Fetal blood and amniotic fluid concentrations of insulin, proinsulin, and $\mathrm{C}$-peptide at various maternal levels of the peptides. The abscissa is plotted as a log scale. Each symbol represents a single animal. The mean values of noninfused rats are circled.

nant rats $(41.0 \pm 4.6 \mu \mathrm{l} / \mathrm{min}$ per $\mathrm{kg})$ than in their littermates $(22.2 \pm 4.1 \mu 1 / \mathrm{min}$ per $\mathrm{kg}, P<0.01)$. However, the renal clearance of insulin which represents the total amount of insulin removed from the circulation by the kidneys was lower in gravid rats, averaging $12.7 \mathrm{ml} / \mathrm{min}$ per $\mathrm{kg}$ nonconceptus weight compared with $15.5 \mathrm{ml} / \mathrm{min}$ per $\mathrm{kg}$ in controls. In contrast to the renal handling of insulin, both the urinary and the renal clearance of $C$-peptide were similar in pregnant and control animals. In accord with observations in male rats (6), the urinary clearance of $\mathrm{C}$-peptide and the fraction of its $\mathrm{MCR}$ attributable to renal clearance were higher than those of insulin.

\section{DISCUSSION}

These data are in accord with previous reports that the MCR of insulin increases late in pregnancy (14). Our results extend such observations by demonstrating that the increased metabolism pertains only to insulin since proinsulin and $\mathrm{C}$-peptide had metabolic clearance rates which were similar in both gravid and virgin littermate rats. Finally, like insulin, the placental permeability of proinsulin and $\mathrm{C}$-peptide is minimal. Thus, the metabolism of all three peptides takes place within maternal tissues.

Others have demonstrated that the half-disappearance time of ${ }^{131}$ I-insulin from the circulation of pregnant rats was approximately $25 \%$ faster than in nonpregnant littermates (14). Because even lightly iodinated insulin may not be metabolized identically to the native hormone (15), we felt that it was important to confirm these findings with unlabeled insulin. The present results indicate that the MCR in term-pregnant rats (20th gestational day) is more rapid than in controls. Furthermore, the magnitude of the difference between the two groups, both in absolute terms or when related to nonconceptus body weight, is in the same range as found by other investigators using different methods (14). To facilitate comparison of our findings with those of others, we measured the peripheral metabolism of insulin both after a single intravenous injection of the hormone and subsequent to the discontinuance of a constant infusion.

TABLE II

Renal Handiing of Insulin and C-Peptide in Pregnant Rats and Virgin Littermates*

\begin{tabular}{|c|c|c|c|c|c|c|c|c|c|c|c|}
\hline & & $\begin{array}{l}\text { Body } \\
\text { weight }\end{array}$ & $\mathrm{C}_{\text {In }}$ & $\mathrm{CPAH}$ & $E_{P A H}$ & $\mathrm{RPF}$ & $\begin{array}{l}\text { Urinary } \\
\text { clearance }\end{array}$ & $\begin{array}{l}\text { Fractional } \\
\text { clearance }\end{array}$ & $\begin{array}{c}\text { Renal } \\
\text { arteriovenous } \\
\text { difference }\end{array}$ & $s \quad \begin{array}{c}\text { Renal } \\
\text { clearance }\end{array}$ & $\begin{array}{c}\text { Renal } \\
\text { clearance/ } \\
\text { MCR }\end{array}$ \\
\hline & $n$ & $g$ & $\mathrm{ml} / \mathrm{min}$ & $\mathrm{ml} / \mathrm{min}$ & $\%$ & $m l$ min & $\mu l /$ min per $k g$ & $\%$ & $\%$ & mlimin per $\mathrm{kg}$ & $\%$ \\
\hline $\begin{array}{l}\text { Insulin } \\
\text { Pregnant } \\
\text { Control } \\
P\end{array}$ & 12 & $\begin{array}{l}207 \pm 5 \\
193 \pm 4 \\
<0.05\end{array}$ & $\begin{array}{c}2.62 \pm 0.10 \\
2.45 \pm 0.09 \\
\text { NS }\end{array}$ & $\begin{array}{c}6.62 \pm 0.26 \\
6.59 \pm 0.36 \\
\text { NS }\end{array}$ & $\begin{array}{c}85.5 \pm 1.3 \\
86.4 \pm 2.3 \\
\text { NS }\end{array}$ & $\begin{array}{c}7.76 \pm 0.32 \\
7.59 \pm 0.23 \\
\text { NS }\end{array}$ & $\begin{array}{c}41.0 \pm 4.6 \\
22.2 \pm 4.1 \\
<0.01\end{array}$ & $\begin{array}{c}0.32 \pm 0.03 \\
0.18 \pm 0.04 \\
<0.02\end{array}$ & $\begin{array}{c}33.8 \pm 1.6 \\
39.0 \pm 1.9 \\
<0.05\end{array}$ & $\begin{array}{c}12.69 \pm 0.80 \\
15.51 \pm 0.95 \\
<0.05\end{array}$ & $\begin{array}{c}19.4 \pm 1.5 \\
28.7 \pm 3.7 \\
\quad<0.05\end{array}$ \\
\hline $\begin{array}{l}\text { C-Peptide } \\
\text { Pregnant } \\
\text { Control } \\
P\end{array}$ & 12 & $\begin{array}{l}211 \pm 7 \\
185 \pm 4 \\
<0.005\end{array}$ & $\begin{array}{c}2.22 \pm 0.12 \\
2.12 \pm 0.11 \\
\mathrm{NS}\end{array}$ & $\begin{array}{c}5.30 \pm 0.18 \\
5.02 \pm 0.28 \\
\text { NS }\end{array}$ & $\begin{array}{c}79.6 \pm 2.6 \\
80.7 \pm 2.8 \\
\text { NS }\end{array}$ & $\begin{array}{c}6.71 \pm 0.36 \\
6.25 \pm 0.34 \\
\mathrm{NS}\end{array}$ & $\begin{array}{c}169.0 \pm 29.6 \\
221.3 \pm 60.9 \\
\text { NS }\end{array}$ & $\begin{array}{c}1.84 \pm 0.20 \\
2.05 \pm 0.60 \\
\mathrm{NS}\end{array}$ & $\begin{array}{c}35.6 \pm 3.1 \\
38.0 \pm 2.7 \\
\text { NS }\end{array}$ & $\begin{array}{c}11.92 \pm 1.64 \\
12.84 \pm 1.00 \\
\mathrm{NS}\end{array}$ & $\begin{array}{c}50.1+5.0 \\
54.1 \pm 4.5 \\
\text { NS }\end{array}$ \\
\hline
\end{tabular}

* Same as Table I. 
In each instance the disappearance of insulin was faster in the pregnant animals. However, because the data did not conform to a single exponential decay curve, it was not possible to calculate the half-disappearance time with accuracy. As we did not measure the blood sugar levels in animals given single injections of insulin, the possibility that hypoglycemia may have affected the disappearance curves cannot be excluded with certainty.

The metabolism of $\mathrm{C}$-peptide and proinsulin in the pregnant and control animals is in marked contrast to that of insulin. The MCR's of both peptides were similar in the two groups of animals, and the disappearance curves of C-peptide after discontinuance of the constant infusions were almost superimposable. Furthermore, in keeping with previous observations in nonpregnant rats (6), swine (16), and baboons (16), the metabolism of proinsulin and $\mathrm{C}$-peptide was considerably slower than that of insulin. It is also of interest that the MCR of insulin in control rats was similar to that previously reported in male animals (6), while the MCR of insulin in pregnancy was more rapid.

To evaluate possible causes for the difference between the metabolic rates of insulin, on the one hand, and proinsulin and C-peptide on the other, experiments were designed to determine whether these peptides enter the fetal circulation. Placental permeability to the peptides was assessed after raising the maternal plasma concentrations to levels as high as $80 \mathrm{ng} / \mathrm{ml}$. However, the concentrations in fetal blood and amniotic fluid remained very low. Goodner and Freinkel (17) conducted similar experiments with ${ }^{131} \mathrm{I}$-insulin in rats and concluded that appreciable transplacental passage of insulin could not be demonstrated. The findings of Buse et al. (18), Wolf et al. (19), and Spellacy et al. (20) also indicate that the placenta represents a substantial barrier to the transport of insulin in humans. On the other hand, the possibility that the placenta may not be completely impermeable to insulin in the rat (21) as well as in other species (22-24) has been suggested by other investigators.

The kidneys play a major role in the peripheral metabolism of polypeptide hormones (6). Therefore, the renal metabolism of insulin and C-peptide were evaluated in pregnant animals. Although the urinary clearance of insulin was higher in gravid rats than in controls, it represented only a minute fraction $(0.32$ and $0.18 \%$ respectively) of the total amount of insulin degraded by the kidneys in both groups. Obviously, the difference in the urinary clearance of insulin was too insignificant to account even in part for the observed increment in insulin MCR in pregnancy.

The higher MCR of insulin in gravid animals could not be explained by enhanced renal clearance either. On the contrary, the renal clearance of insulin was lower in pregnant rats, and therefore the fraction of the MCR accounted for by renal clearance was substantially less in this group $(19.4 \%)$ than in littermate controls $(28.7 \%)$. In contrast, the renal excretion and extraction of C-peptide and the contribution of renal clearance to the MCR of this polypeptide were similar in pregnant and control animals.

These results clearly indicate that neither transplacental passage nor enhanced renal extraction can account for the higher MCR of insulin in pregnancy. However, sequestration and degradation of insulin by the placenta have been demonstrated in a number of studies. Thus Goodner and Freinkel showed that rat (25) and human (26) placental homogenates exhibited considerable insulin-degrading activity which increased in parallel with the placental mass as pregnancy advanced. Moreover, the placental-degrading activity in rats was equal to that of the liver per unit of nitrogen and its total activity reached one-third of the value of the maternal liver at term (25). Although the quantitative contribution of the placenta to insulin meabolism in vivo will require measurement of blood flow and arteriovenous concentration differences across the placenta, it is likely that this tissue is mainly responsible for the more rapid metabolism of insulin in pregnancy. This view is supported by the observation that insulin turnover returns towards normal shortly after expulsion of the placenta (14). In contrast to insulin, it seems probable that proinsulin and C-peptide are not sequestered or degraded by the placenta. Whether this selectivity is a function of placental receptors or of enzyme specificity is at present uncertain.

\section{ACKNOWLEDGMENTS}

We thank Mrs. Roberta Lagocki, Miss Margaret Lorincz, and Mrs. Felice Rio for excellent technical assistance and Mrs. Gail Sims for the preparation of the manuscript.

This work was supported by grants AM13601, HD05572, and HD07110 from the National Institutes of Health and by the Chicago and Illinois Heart Associations (Adrian I. Katz and Marshall D. Lindheimer), and by grant AM13941 from the National Institutes of Health and Diabetes-Endocrinology Center Grant P17 AM17046 (Arthur H. Rubenstein).

\section{REFERENCES}

1. Bleicher, S. J., J. B. O'Sullivan, and N. Freinkel. 1964. Carbohydrate metabolism in pregnancy. V. The interrelations of glucose, insulin and free fatty acids in late pregnancy and post partum. N. Engl. J. Med. 271: 866-872.

2. Rubenstein, A. H., M. E. Mako, J. I. Starr, D. J. Juhn, and D. Horwitz. 1974. Circulating proinsulin in patients with islet cell tumors. Excerpta Med. Int. Congr. Ser. 312: 736-752.

3. Mako, M. E., M. Block, J. I. Starr, E. Nielson, E. Friedman, and A. H. Rubenstein. 1973. Proinsulin in chronic renal and hepatic failure: a reflection of the 
relative contribution of the liver and kidney to its metabolism. Clin. Res. 21: 631. (Abstr.)

4. Gorden, P., C. M. Hendricks, and J. Roth. 1974. Circulating proinsulin-like component in man: increased proportion in hypoinsulinemic states. Diabetologia. 10: 469474.

5. Freinkel, N. 1965. Effects of the conceptus on maternal metabolism during pregnancy. Excerpta Med. Int. Congr. Ser. 84: 679-691.

6. Katz, A. I., and A. H. Rubenstein. 1973. Metabolism of proinsulin, insulin, and C-peptide in the rat. $J$. Clin. Invest. 52: 1113-1121.

7. Rubenstein, A. H., L. A. Pottenger, M. Mako, G. S. Getz, and D. F. Steiner. 1972. The metabolism of proinsulin and insulin by the liver. J. Clin. Invest. 51: 912-921.

8. Tait, J. F. 1963. Review: The use of isotopic steroids for the measurement of production rates in vivo. $J$. Clin. Endocrinol. Metab. 23: 1285-1297.

9. Gorden, P., and J. Roth. 1969. Plasma insulin: fluctuations in the "Big" insulin component in man after glucose and other stimuli. J. Clin. Invest. 48: 2225-2234.

10. Melani, F., A. H. Rubenstein, P. E. Oyer, and D. F. Steiner. 1970. Identification of proinsulin and C-peptide in human serum by a specific immunoassay. Proc. Natl. Acad. Sci. U. S. A. $67: 148-155$.

11. Davidson, W. D., and M. A. Sackner. 1963. Simplification of the anthrone method for determination of inulin in clearance studies. J. Lab. Clin. Med. 41: 351356.

12. Smith, H. W., N. Finkelstein, L. Aliminosa, B. Crawford, and M. Graeber. 1945. The renal clearance of substituted hippuric acid derivatives and other aromatic acids in dog and man. J. Clin. Invest. 24: 388-404.

13. Morgan, C. R., and A. Lazarow. 1963. Immunoassay of insulin: two antibody system. Plasma insulin levels of normal, subdiabetic and diabetic rats. Diabetes. 12 : $115-126$.

14. Goodner, C. J., and N. Freinkel. 1960. Carbohydrate metabolism in pregnancy: The turnover of $\mathrm{I}^{131}$-insulin in the pregnant rat. Endocrinology. 67: 862-872.
15. Genuth, S. M. 1972. Metabolic clearance of insulin in man. Diabetes. 21: 1003-1012.

16. Stoll, R. W., J. L. Touber, L. C. Winterscheid, J. W. Ensinck, and R. H. Williams. 1971. Hypoglycemic activity and immunological half-life of porcine insulin and proinsulin in baboons and swine. Endocrinology. 88: 714-717.

17. Goodner, C. J., and N. Freinkel. 1961. Carbohydrate metabolism in pregnancy. IV. Studies on the permeability of the rat placenta to $\mathrm{I}^{131}$ insulin. Diabetes. 10: 383392.

18. Buse, M. G., W. J. Roberts, and J. Buse. 1962. The role of the human placenta in the transfer and metabolism of insulin. J. Clin. Invest. 41: 29-41.

19. Wolf, H., V. Sabata, H. Frerichs, and P. Stubbe. 1969. Evidence for the impermeability of the human placenta for insulin. Horm. Metab. Res. 3: 175-179.

20. Spellacy, W. N., W. C. Buhi, B. Bradley, and K. K. Holsinger. 1973. Maternal, fetal and amniotic fluid levels of glucose, insulin and growth hormone. Obstet. Gynecol. 41: 323-331.

21. Knobil, E., and J. B. Josimovich. 1959. Placental transfer of thyrotropic hormone, thyronine, triiodiothyronine, and insulin in the rat. Ann. N. Y. Acad. Sci. 75: 895904.

22. Josimovich, J. B., and E. Knobil. 1961. Placental transfer of $\mathrm{I}^{131}$-insulin in the rhesus monkey. Am. J. Phy'siol. 200 : 471-476.

23. Mintz, D. H., R. A. Chez, and E. O. Horger, III. 1969. Fetal insulin and growth hormone metabolism in the subhuman primate. J. Clin. Invest. 48: 176-186.

24. Bitlin, D., J. Kumate, and C. Morales. 1965. On the transport of insulin across the human placenta. Pediatrics. 35: 65-69.

25. Goodner, C. J., and Freinkel, N. 1959. Carbohydrate metabolism in pregnancy: the degradation of insulin by extracts of maternal and fetal structures in the pregnant rat. Endocrinology. 65: 957-967.

26. Freinkel, N., and C. J. Goodner. 1960. Carbohydrate metabolism in pregnancy. I. The metabolism of insulin by human placental tissue. J. Ciin. Invest. 39: 116-131. 